\title{
Profiles in Intelligence: An Interview with Professor Richard J. Aldrich
}

\author{
Mark Phythian
}

\section{Introduction}

Richard J. Aldrich, Professor of International Security at the University of Warwick, is one of the key figures in the development of Intelligence Studies in the UK and internationally. A historian by training and author of several landmark historical studies of US and UK intelligence, his contribution to Intelligence Studies also lies in the consciously interdisciplinary approach he has taken to the subject, working at the interface of History and Politics while also emphasising the importance of technology and culture to the study of intelligence.

He was born in Rochdale in 1961. After leaving school he joined the Army before taking a degree in History at the University of Manchester. Graduating with a First Class honours degree, he studied for a Master's degree in Strategic Studies at the University of Aberdeen, before moving to Corpus Christi College, Cambridge for his $\mathrm{PhD}$. This would form the basis of his first monograph, The Key to the South: Britain, the United States and Thailand During the Approach of the Pacific War, 1929-1942, published by Oxford University Press in 1993.

By this time, Richard Aldrich had helped to establish the pioneering Intelligence Studies programme at the University of Salford, where he was a Lecturer in the Department of Politics and Contemporary History from 1989 to 1991, spent a year as a Fulbright Fellow at Georgetown University, and taken up a post in the School of Politics at the University of Nottingham. He also began to publish a series of substantive articles on intelligence themes, several of them published in Intelligence and National Security during the 1990s. He became its book reviews editor in 1990 and continued in this role until 1995, when he became coeditor of Intelligence and National Security. Alongside Wesley Wark, the other co-editor at this time, he played a hugely important role in the development of the journal. Richard would remain co-editor for eight years, stepping down from the role in 2003.

During this period Richard Aldrich published two major monographs which cemented his reputation as a leading figure in this rapidly developing field; the 500-page Intelligence and 
the War Against Japan: Britain, America and the Politics of Secret Service in 2000 and the 750-page The Hidden Hand: Britain, America and Cold War Secret Intelligence in 2001. In the following years he published a series of important articles at the interface of historical and social science approaches to the study of intelligence, some of which also addressed issues of technology and culture, areas of increasing interest to him. In 2007 he moved to the University of Warwick and from there published his landmark history of GCHQ in 2010 and led the Arts and Humanities Research Council (AHRC)-funded project on Landscapes of Secrecy: The CIA and the Contested Record of US Foreign Policy 1947-2001, ${ }^{1}$ which resulted in a series of publications including a special issue of the journal History in 2015. Richard Aldrich's contribution to the development of Intelligence Studies is even broader than this outline sketch of his career suggests and has extended to publications focusing on methodological issues in the study of intelligence, edited volumes of intelligence and security documents, and readers that can form a basis for teaching intelligence. Moreover, his contribution to the field is evident in the number of $\mathrm{PhD}$ students he has supervised to successful completion, many of whom have gone on themselves to hold posts in universities and make significant contributions to the study of intelligence. He has also played an active role in popularising and explaining intelligence beyond the university. He has acted as a consultant to television projects with an intelligence dimension, most recently the television documentary Spying on the Royals (Channel 4, 2017), as well as appearing regularly on television news and current affairs programmes as a commentator on intelligence matters and producing short pieces for popular magazines and quality daily newspapers alike on intelligence topics. His most recent monograph, co-authored with Rory Cormac, is The Black Door: Spies, Secret Intelligence and British Prime Ministers, published in 2017. In the same year he was awarded the International Studies Association Intelligence Studies Section Distinguished Scholar Award in recognition of his impact on the field of Intelligence Studies. What follows in the edited transcript of an interview conducted with Richard Aldrich at the University of Warwick on $12^{\text {th }}$ December 2017.

\section{Interview}

\footnotetext{
${ }^{1}$ See, https://warwick.ac.uk/fac/soc/pais/research/researchcentres/irs/landscapes.
} 
MP: How did your interest in intelligence originate? I would imagine that when you were an undergraduate student the landscape in terms of the study of intelligence would have been quite barren.

RA: I suppose that my first awareness of intelligence came when I left school. I didn't go straight to university, I went into the Army for a little bit in Germany and Norway. My sergeant was trying to move out of my unit and into the Intelligence Corps and I was aware that people from my unit had gone off to serve in something called the British Services Security Organisation, which was like a second-rate MI5 run by the Army. We were all issued with SOXMIS cards, which were the recognition documents for the Soviet equivalent of BRIXMIS. We had all these people driving around the allied zones in Germany as SOXMIS. ${ }^{2}$ Our barracks in Germany was also attacked by the IRA. I think my time in the Army meant that I was already interested in that kind of stuff, but it is funny how these things happen. When I went to university in Manchester I wanted to work on Ancient Greece. I wanted to work on Pericles, on the Peloponnesian war. In my second year I spent about six months learning Ancient Greek and went to all sorts of summer schools. But when I turned up at the start of my third year and they said: 'Terribly sorry, the course on the Peloponnesian war has been cancelled and we don't know what to do with you. Almost all the special subjects are full up, but there's this course on Wars in the Pacific run by Peter Lowe ${ }^{3}$. Peloponnesian war, Pacific war, there's not much difference. It's a war, so I said 'Okay'. Quickly, I moved from the $5^{\text {th }}$ century BC to studying the wars in the Pacific, including Vietnam. Overnight I was plunged from Periclean Athens into the Public Records Office (PRO, later to become the National Archives) and I chose to work on the British re-occupation of South East Asia, which was actually led by SOE although I didn't know what it was. I got into the PRO archives in Christmas 1982 and I was trying to look at these Foreign Office files on Britain's thinking about re-occupying South East Asia, and there was this organisation called SOE (Special Operations Executive). And occasionally this organisation called SIS (Secret Intelligence Service - aka MI6), and I ended up writing my undergraduate dissertation about this. This was a complete accident. I started my third year at

\footnotetext{
${ }^{2}$ For background on this 'legal spying' see https://coldwar.org.uk/soxmis-and-brixmis-legal-spying-on-thefront-lines-of-the-cold-war/.

${ }^{3}$ Historian of the Asia-Pacific region. See the obituary from The Independent, $24^{\text {th }}$ February 2012, at: https://www.independent.co.uk/news/obituaries/doctor-peter-lowe-historian-of-the-asia-pacific7440090.html.
} 
university expecting to be reading Thucydides and by the end of it I was looking at SOE files in the PRO.

MP: Is that what led you to go to Aberdeen to take the M.Litt. in Strategic Studies?

RA: No, really I went to Aberdeen because as a third year undergraduate there is a question of 'what will I do next?' and I didn't think I would get the grades to do a $\mathrm{PhD}$. I wanted to work for the government, probably in the Ministry of Defence, and so I went to do this course because it had a lot of defence economics. I look back on it and it was hugely important because at a pretty early stage I was taken out of a History department (at Manchester) and put in a Strategic Studies/International Relations environment (at Aberdeen) and from that moment I've been interested in that cross-disciplinary thing. I suppose if I wanted to talk about how I think, the thing that has shaped what I am doing now is still that Master's degree in the early 1980s, which only had four students on it.

MP: And that leads directly to the $\mathrm{PhD}$ at Cambridge?

RA: Well, really from that time on I was just trying to find somewhere that would take me on as a PhD student. I knew I had to work in the archives. Again, I was going to work on this fascinating period of the 1940s and had already worked out that SOE disappeared and became something else. I still wanted to work on the Japanese occupation of South East Asia and I went for an interview at Corpus Christi College, Cambridge and I was interviewed by an engineer. I was quite cross, wondering why I was being interviewed by an engineer for a $\mathrm{PhD}$ in the humanities. But this engineer was actually a guy called Richard Bainbridge who had been a Major in the British army occupying Vietnam at the end of the Second World War, which is why he was interviewing me. The British re-armed the Japanese to fight the Viet Minh in this weird period and he had commanded 1,000 Japanese troops around Saigon airfield where he had fought the Viet Minh in 1945. So, they fielded him because he knew exactly what I had come to work on. That's how I moved from Aberdeen to Cambridge.

MP: Was Christopher Andrew your PhD supervisor?

RA: No, he wasn't, although I think Wikipedia sometimes suggests that he was. But Chris was extremely helpful. During this period I was really working on Britain in South East Asia in the 1940s and SOE. Its translation into MI6 was hugely important in shaping British policy and I would take stuff and show it to Chris and I would say: 'What's this?'; 'What do you think of this?'; 'Is this ULTRA, is this SIGINT?' Chris was advising me and encouraging me right from 
the start. The first article I wrote was for Intelligence and National Security ${ }^{4}$ because of course he was setting all that up when I was in Corpus and it was very exciting. There was another $\mathrm{PhD}$ student there called Richard Popplewell. He was working on intelligence in India and Chris Andrew sent us both off to a conference run by Michael Handel in about 1986 at Carlisle Barracks in Pennsylvania. Michael Handel used to run these amazing conferences there, and that was really I think my first induction. I look back, and I didn't realise it at the time, but I had moved over from the field of diplomatic history. I often think that in that period of the 1980s Intelligence Studies was a kind of refugee camp for diplomatic historians who had become bored with diplomatic history. I look back and I can see that I was one of them. My mate Richard Popplewell, who was doing a PhD with Chris Andrew, was Intelligence Studies from the start - whereas so many of us were defectors from military history and diplomatic history. Chris Andrew sent us both off to this conference and there were all these practitioners - people like David Hunt who had been Cabinet Secretary, who had run deception - and it was intoxicating. It was like your first glass of beer.

I was also a defector to Intelligence Studies because by the time I got to the third year of my $\mathrm{PhD}$ I realised I had been doing the wrong $\mathrm{PhD}$. This happened to so many of us. I did a $\mathrm{PhD}$ on the outbreak of the Second World War in South East Asia and instead I should have been doing a PhD on the US Office of Strategic Services (OSS) and SOE. That was actually my second book, but it is the PhD I should have written if only I had been clued up enough to know. Really, it was just discovering Intelligence Studies quite late, others like Wesley Wark were already doing amazing $\mathrm{PhDs}$ on intelligence. I was always aware it was a theme, but it never occurred to me that I could do a $\mathrm{PhD}$ on it. And of course, this is partly connected to methodology. I was finding SOE material even as an undergraduate in Christmas 1982 in various files, but of course there were no SOE files at the time. Methodology was something that Chris Andrew was essentially writing his manifesto about when he did The Missing Dimension in July $1984 .{ }^{5}$ He was saying to people - look, actually if you go into the archives you can find a lot of stuff. It is possible to write articles, even books, about intelligence even though the intelligence services haven't released their files.

\footnotetext{
4 Then co-edited by Christopher Andrew. The article was 'Imperial Rivalry: British and American Intelligence in Asia, 1942-6', Intelligence and National Security, Vol.3, No.1 1988: 5-53.

${ }^{5}$ Christopher Andrew and David Dilks (eds.), The Missing Dimension: Governments and Intelligence Communities in the Twentieth Century (London: Macmillan, 1984).
} 
MP: Yes, around the same time you are making this transition there is an explosion of interest in the study of intelligence; Intelligence and National Security is founded, the International Journal of Intelligence and Counterintelligence is founded, The Missing Dimension book is published, and Chris Andrew's Secret Service book comes out at around the same time, ${ }^{6}$ which all must have been very inspiring.

RA: I think Chris Andrew has this fantastic sort of catalytic effect. Clearly, a number of historians, people like Keith Wilson, people like David Dilks, had worked on diplomatic history, knew a lot about intelligence and had tremendous expertise to bring to bear. That is why I think The Missing Dimension is so fantastic. Typically, the essay in that collection which is decades ahead of its time is the David Dilks essay about communications security (COMSEC) and Britain's failure of communications security. The book brings together all these people who actually have quite a lot of knowledge about intelligence but hadn't thought about it as a discipline, as a subject, as an approach and I often think that coming together of Chris Andrew and David Dilks was very important. And the fabulous essay by David Dilks in that collection is about British COMSEC in Italy ${ }^{7}$ - John Ferris addresses it ten years later, Rebecca Ratcliffe addresses it twenty years later, but David Dilks is twenty years ahead of his time. I think that was a genuinely important collection whereas so many collections of essays are forgotten and sit on library shelves gathering dust.

MP: The academic study of intelligence is clearly about to take off. Can you recall much of the literature of the time? Where you would look to read about intelligence?

RA: Yes, the three people who were hugely influential are Bradley Smith, David Stafford and Julian Lewis. They were all masters of this technique of 'lateral research'. There were no SOE files, there were no MI5 files. Nowadays when Chris Andrew sends a new PhD student down to the National Archives it is a case of 'What is in the latest thousand files released by the Security Service?' You couldn't do that in the 1980s. You had to find other departments that worked with the security agencies and hope that they had re-circulated carbon copies - a kind of lateral approach. Peter Hennessy, then the Times Whitehall correspondent, used the same technique and has called it 'PRO hacking'. Bradley Smith had written a book about OSS and

\footnotetext{
${ }^{6}$ Christopher Andrew, Secret Service: The Making of the British Intelligence Community (London: William Heinemann, 1985).

${ }^{7}$ David Dilks, 'Flashes of Intelligence: The Foreign Office, the SIS and Security Before the Second World War', in Andrew and Dilks (eds.), The Missing Dimension: 101-25.
} 
to some extent SOE, Shadow Warriors, by deploying exactly this technique. ${ }^{8}$ And Bradley used to say that he tried to get into the mind of the filing clerk. He tried to think how they would file stuff. David Stafford had written a book about SOE and the European resistance using chiefs of staff files. ${ }^{9}$ But the most under-recognised was Julian Lewis, who did a thesis with Michael Howard on how the British chiefs of staff, the Joint Planning Staff and the Joint Intelligence Committee (JIC), began to think about the Russians in the last three or four years of the Second World War. ${ }^{10}$ This technique of lateral research was hugely influential. The other thing that was hugely influential was just the climate of secrecy - Margaret Thatcher's obsession with Spycatcher, the Blunt case, etc. A good example was the official history of intelligence in the Second World War commissioned under the Heath and Wilson governments. Thatcher didn't like it and actually opposed it. When she was the Leader of the Opposition, Prime Minister James Callaghan had consulted Thatcher, and when she comes into power there is the Blunt stuff, the GCHQ strike, and she actually blocks the publication of the official history in mid-process. So there was this climate of intense secrecy. The things that Bradley Smith, David Stafford and Julian Lewis were teaching us seemed incredibly naughty; it felt like an anti-state activity and it was great fun.

MP: This backdrop also gives rise to a number of journalistic accounts. Did they help to inspire you?

RA: Yes, I remember when I was doing my Master's degree in Aberdeen, this was 1983-84, Chris Andrew's book [Secret Service] wasn't available until 1985, so what do you read at that point? I was a fanatical reader of Nigel West and Duncan Campbell. And although Nigel West had not yet discovered the PRO and although these were thought of as popular texts, I think Duncan Campbell and Nigel West were incredibly important in underlining that these were not impossible research topics.

MP: This must have been an exciting time to be studying intelligence. As a subject, it went from something that was very difficult to study, to people like Chris Andrew paving a way by showing that this is how you can study it and people like yourself were part of the first successor generation, if you like, who were in the archives doing the work.

\footnotetext{
${ }^{8}$ Bradley F. Smith, The Shadow Warriors: OSS and the Origins of the CIA (London: André Deutsch, 1983).

${ }^{9}$ David Stafford, Britain and the European Resistance, 1940-1945: A Survey of the Special Operations Executive, with Documents (London: Macmillan, 1980).

10 Published as Julian Lewis, Changing Direction: British Military Planning for Post-War Strategic Defence, $1942-$

47 (London: Sherwood Press, 1988).
} 
RA: My problem was really that in the late 1980s and early 1990s I was working on two things. I was trying to finish the book on Intelligence and the War Against Japan, which took me ages and ages. It took me ages because all my mates were working on the first five years of the Cold War and that was also very interesting. A lot of the documents which I then used for a later book on the Cold War, The Hidden Hand, was material I had gathered at the same time. My breakthrough came through going down to the PRO on the wrong day. I had forgotten that they used to have stock-taking days when they just closed for a day in the middle of the week and counted their files to make sure that none were missing. I turned up at the PRO and it was a stock-taking day and they were shut. And I thought 'what else can I do?'. I had always meant to go to the India Office (library and records) over in Blackfriars - I'll go there today I thought. It is a peculiar thing, all British government archives kept in Britain go to the PRO except for the files of the India Office. This is because in 1947 when Britain and India were negotiating independence, Nehru said not only do I want to keep all of the government files that were generated and stored in Delhi, I want all the files on India that are kept in London, so they've got to be shipped out from London. The British government said 'they're ours; India Office is ours, Indian government in Delhi, that's your stuff.' This became almost the last sticking point in the transfer of power negotiations. The compromise they came up with was that the files of the India Office would stay in London but they would never be incorporated into the PRO, they would be given this semi-independent status. And that is why the India Office library and records existed as a separate building at Blackfriars. The other effect of this was the weeders never got their hands on the India Office files. Although the India Office files mostly stop in 1949 this is a time when you can't see a JIC paper, you certainly can't see a JIC paper from after 1945, or any of these interesting intelligence papers about the early Cold War. And I turn up at the India Office on a cold, rainy day in February 1987, I think. 'What have you got?' 'Well, have a look at these War Staff files'. And I'm looking down these War Staff files and there are files that are just open - JIC 1948, reforms to British Intelligence 1948, SIGINT targets 1948 - which now sound mundane, but I was shaking. I actually had to go out of the building, walk round the building and catch my breath. I came back in and I remember putting in these three slips and the first file that turned up on my desk was 'JIC Review of SIGINT Targets 1948 '. I just thought that at any moment someone was going to come out from around the back and say 'you shouldn't have those, give them to me.' And actually, this JIC paper for 1948 is still closed in the National Archives, but this was the one that got away. It was accidental lateral research. I had turned up at the PRO and it was shut, so I went to the India Office. 
MP: While you are working on this in the early 1990s you are also, of course, teaching in universities, and at Salford University you are involved in developing one of the earliest Master's courses in intelligence.

RA: Yes, my first job was at the University of Leeds, which was a temporary job. Then I moved to Salford, and Salford was I think probably the first department to identify itself as a centre of Intelligence Studies. It wasn't the first Master's degree, the first Master's degree, I think, was Rhodri Jeffreys-Jones' at the University of Edinburgh on American intelligence which was running certainly in the mid-1980s, but it was mainly a Master's by research - it was a classic History dissertation-led Master's. When I got to Salford the Head of Department, Mike Goldsmith, who was also head of Political Studies Association, said he wanted to develop Intelligence Studies. We had Ralph White, who was an SOE expert, we had Ted Harrison who was doing SOE, a number of other people who worked on some aspect of intelligence, like Sheila Kerr. And I was given the job of putting together a Master's in Intelligence and International Relations.

MP: In developing that award you had very little to go on, because there weren't lots of courses out there. How did you decide what a Master's course on intelligence should include?

RA: Well, I think it was wrong to call it 'Intelligence and International Relations', because we were mostly historians. I think it was because you did some modules in intelligence, which were intelligence history, and you did a bit of IR on the side. There were classic trainspotter modules on SOE, the KGB, which were very institutional. The formative influence at that time was the fact that a guy called Roy Godson in America had got money from the Bradley Foundation to run a series of summer schools on the teaching of intelligence. And so at the same time as I was doing that with Mike Goldsmith, Ralph White and Ted Harrison, Roy Godson was offering these summer schools where essentially they had money to pay for you to go off and spend a couple of weeks. I went to Bowdoin College in Maine, and there's Roy Godson, Dick Schultz turned up from Tufts, Abe Shulsky. Godson at that time was riding high, it was the tail end of the Reagan era and he was on the President's Foreign Intelligence Advisory Board, with really high connections. I remember going to this thing in Maine, a really beautiful college in the summer, and he turned out amazing speakers like Bill Colby who had been DCI, Hugh Tovar the former head of CIA covert action, Ted Shackley former head of the JMWAVE CIA station in Florida, several FBI figures... 
MP: And the purpose was to promote thinking about how you would frame the teaching of intelligence?

RA: It was to tackle precisely this issue of 'how are we going to teach intelligence?' How is it going to be organised? He was one of the first people to formulate this functional approach let's look at collection, let's look at analysis, let's look at covert action, let's look at deception - identifying five or six functional themes. He is also the first person to be circulating syllabi. We turn up and we get a load of syllabi, this is what is being done at Tufts, this is what is being done at Vanderbilt, and so on. This is five years before there is a big push from the Center for the Study of Intelligence and the CIA's experiment with academic engagement, so I don't really know where that came from, I can only say that it was hugely helpful. Both myself and Sheila Kerr also suddenly realised that the Americans, people like Loch Johnson and Bob Jervis, were far ahead of the UK in linking intelligence and International Relations.

MP: So you came back with clear ideas about how to frame syllabi in intelligence?

RA: Absolutely, and because I was regularly going to Washington, DC to mine the archives I would regularly reconnect with Roy Godson and some of these other people. The other thing that Roy Godson was important in doing is making it clear to me that it was actually quite easy to meet up with practitioners and that there were practitioners who were keen to see Intelligence Studies get going. All these things linked together. I was at Salford until 1990, then I got a job at the University of Nottingham, but with a year at Georgetown University in between. This meant that I had a whole year hanging out with practitioners. What Godson had done is break down that 'imposter syndrome', the idea that you were an academic and people didn't want to speak to you. Actually, people did want to speak to us and after you had been around to their house for the third time they would tell you stuff! I was lucky to get that year in Georgetown in 1990-91, not least because Bill Colby lived about five minutes' walk from my office. I spent time with Cord Meyer and Ray Cline and so many interesting people.

MP: How did all this feed into and shape your understanding of what Intelligence Studies was? Did you think in terms of Intelligence Studies at that point, or did you think in terms of being an intelligence historian? I ask partly because from the mid-1990s you become an editor of Intelligence and National Security and I'm wondering if you had a vision of what the journal should look like rooted in ideas of the nature of Intelligence Studies?

RA: I think the moment where things went backward for me a little bit at that time is that I left Salford where there were four or five people who were interested in this stuff and we were 
running a degree in intelligence and I moved, via Georgetown, to a department that wasn't doing this stuff and was quite small. I spent most of my career at Nottingham, sixteen years, and we never ran a degree on this stuff. For most of that time I was the only person working on it. So I was no longer being asked those questions of how would you structure a Master's degree in intelligence. All of a sudden I was just a solo scholar trying to produce big books on intelligence and it was, I think, just because I was sending a lot of my stuff to Intelligence and National Security that I became book reviews editor initially.

I think teaching intelligence makes you think hard about how this subject is going to be organised and what does the discipline consist of. In that sense I think Rhodri Jeffreys-Jones' efforts at Edinburgh were really important in the early 1990s. Places that start to teach intelligence - Salford, Aberystwyth, King's College, London, Brunel - once you have to run a Master's degree and need to develop a syllabus, you are asked those anatomical questions what is our meta-organisational principle? If you are just writing a big book about intelligence in the early Cold War you are asked some questions about causation and about research methodology, but you are not asked those big questions about Intelligence Studies.

Intelligence and National Security was a very happy marriage in the sense that it was someone in a traditional university writing intelligence history in Chris Andrew (although in fact one of the first International Relations articles written from the UK on intelligence was Chris Andrew's 'Whitehall and Washington' published in International Affairs in the 1970s ${ }^{11}$ ), partnered by Michael Handel who was teaching intelligence in a War College in a more strategic studies environment. So it was a nice mix. In talking about the origins of Intelligence Studies, over in the US there were, of course, other people doing intelligence, such as Richard Immerman who was doing path-breaking research on Guatemala. Richard Immerman was writing articles about covert action in the late 1970s-early 1980s and I remember him telling me how he sent an article on Guatemala and covert action to journals, very good journals, and they came back with reviewers' reports saying this is a fantastic article and we should publish it by academic criteria, but we dare not publish it. Eventually, it ends up with Political Science

\footnotetext{
${ }^{11}$ Christopher Andrew, 'Whitehall, Washington and the Intelligence Services', International Affairs Vol.53 No.3 1977: 390-404.
} 
Quarterly. ${ }^{12}$ Greg Treverton's pioneering book on covert action is another example. ${ }^{13}$ It was easier at the time for political scientists to work on current intelligence in the United States. It probably would have been possible for political scientists to work on this in the UK but they were deterred either because they thought methodologically it was not possible, or by the Thatcher climate of secrecy, so I'm really fascinated by how Intelligence Studies in the UK in its origins was much more historical and in the US. Clearly, people like, Richard Betts, Greg Treverton, Richard Immerman and Michael Handel were doing more current stuff. It is crude to map it geographically and say that in the United States academics were pushing the boundaries in terms of political science and theories of surprise attack, while the British were doing their Bletchley Park, but I think that's broadly how it was.

MP: This work that you are doing at the time results in the book The Hidden Hand, the definitive account of the whole US-UK intelligence relationship during the Cold War. What was the most significant thing do you think to come out of that research?

RA: I published quite a big book on intelligence in the Pacific War in 2000 [Intelligence and the War Against Japan], and I published The Hidden Hand the year after. It is one of my besetting sins that I tend to work on several things at once and as I had all these mates working on the early Cold War, it was all very seductive. The year at Georgetown was very important because this was a year in the American archives when I had no teaching and I would just go to the archives and bash 200 boxes a day. And I guess methodologically both books, Intelligence and the War Against Japan - which actually goes up to 1947 - and The Hidden Hand were very general books. The book on the Pacific war has chapters on India, China, Japan, Thailand, Malaysia and The Hidden Hand is, arrogantly, all of British and American intelligence, all regions of the world, between 1943 and 1963. So the beauty of being in Georgetown and going to the National Archives every day while working on these two books simultaneously is that you could just essentially chew your way through the archive ordering as many boxes of anything you could think of, because in any 200 boxes, by the end of the day, you would have found twenty quite interesting documents and two very interesting documents. Because the subject of your inquiry was so general, any body of records you attacked would produce something. So I suppose it was the blunderbuss approach. But, of course, the most

\footnotetext{
${ }^{12}$ Richard H. Immerman, 'Guatemala as Cold War History', Political Science Quarterly, Vol.95 No.4 1980-81: 629-53.

${ }^{13}$ Gregory F. Treverton, Covert Acton: The Limits of Intervention in the Post-War World (New York: Basic Books, 1987).
} 
interesting find was always serendipitous. I was based in Georgetown, I was going to the National Archives every day, but about once every two months I would go off to a presidential library. I'd gone off to Abilene, Kansas, to the Dwight D. Eisenhower Library and I went through the Walter Bedell Smith papers. Everyone knew at that time that things like Radio Free Europe and the Asia Foundation were CIA fronts, but in these papers I came across another CIA front called the American Committee on United Europe (ACUE). It was clear that this foundation had been funnelling money to the early European federalists and it involved 'Wild Bill' Donovan and Walter Bedell Smith. It was clearly another front that was not well known. And I came back to Georgetown, where my best mate was actually the head archivist at the University Library and I mentioned the American Committee on United Europe - adding it's clearly some kind of front organisation for promoting European unity, there's clearly some CIA involvement - and he replied: 'Oh, the American Committee on United Europe, actually we have their papers here in Georgetown library, about 50 files. No one has ever looked at them.' The Committee lasted until the early 1960s, the last person who ran it had died and their widow did not know what it was, didn't know her husband had been running a CIA front organisation, so she just dumped the papers in Georgetown University Library. And the wonderful thing about it is that all the money is there, all the receipts. They funnelled about $£ 4$ million to the European federalists led by Paul Henri Spaak during the 1950s - organised European federalism would virtually died without this CIA support. ${ }^{14}$ Rather like my accidental day in 1987 in the India Office was a day of revelation, this was the discovery that surprised me most in the 1990s.

MP: To move on from the The Hidden Hand, your next book project was the documentary reader published by Manchester University Press in 1998 Espionage, Security and Intelligence in Britain, 1945-1970: Documents in Contemporary History, which demonstrates this lateral approach to intelligence research in archives in the absence of releases from intelligence departments themselves.

RA: The documents collection was almost like a displacement activity while I tried to write The Hidden Hand and couldn't work out how to organise it. It was six months of mental stasis where I was just stuck. This was the time of the new archival openings represented by the

\footnotetext{
${ }^{14}$ See Richard J. Aldrich, 'OSS, CIA and European Unity: The American Committee on United Europe, 1949-1960', Diplomacy and Statecraft, Vol.8, No.1 1997: 184-227. See also Chapter 13 of The Hidden Hand.
} 
Waldegrave initiative; ${ }^{15}$ we're not just going to close the whole file, we're going to redact some stuff and we're going to be more reasonable. Hidden Hand was a mixture of what I had found in the US plus the material that became available via the Waldegrave initiative.

MP: From the vantage point of 2017 the landscape for archival research into intelligence has been transformed. What do you think are the likely limits to this process of liberalisation with regard to intelligence document releases?

RA: Where are we going now? I actually think that the leakers are setting the benchmark, not just Chelsea Manning, not just Edward Snowden, but the latest releases, such as the Panama Papers leak and 18 million FIFA documents. ${ }^{16}$ For people who work on government and public administration, the gravitational focus of oversight is moving away from formal bodies like the UK's Intelligence and Security Committee to the press, even to just the web because Manning didn't even use a journalistic medium, but just released it all. It also means that as researchers if you are a historian you are no longer an official historian at one remove, having to just work against the weeder in the Foreign Office. The problem for me is that going to the National Archives, you are not just going there to look at an inert research subject, instead your research subject is actually in control of the data. It's like being a scientist in a lab looking at a lab rat, but the lab rat is controlling the experiment to a degree. This is not good. So once you get into a period of these vast document dumps, government is no longer in control of history. That not only means physically you can see things which you didn't think you would ever be able to see, but also that it changes the culture. Why is GCHQ embarking on an official history now when it didn't join the party a decade ago? Partly because they appointed a director whose background was public relations, but also because actually in the context of Snowden it doesn't make sense to fight historians over protecting something that was generated in the 1950s when you can read GCHQ Powerpoints from 2008 made available via Snowden.

MP: So the implication is that the leakers of today's secrets impact on the weeders of yesterday's files and have a liberalising impact on file release policy?

RA: Yes and it is also international, so I think the great treasure troves are going to be what comes out of Libya, what comes out of Sudan, what have the South Africans got from the 1980s

\footnotetext{
${ }^{15}$ On this, see Richard J. Aldrich, 'The Waldegrave Initiative and Secret Service Archives: New Documents and New Policies', Intelligence and National Security, Vol.10, No.2 1995: 192-7.

${ }^{16}$ See, 'Panama Papers: A Special Investigation', at https://www.theguardian.com/news/series/panamapapers.
} 
and 1990s, what are we going to get from Brazil, etc. There is so much stuff, it is going to be really exciting. For example, we know that the Americans listened in to pretty much every word that Yasser Arafat said on the phone and at some point in the next ten years I think we are going to be able to read that, to be able to read every word that Yasser Arafat said on the phone. I feel quite ambivalent about this. On the one hand there are issues of privacy-snooping - but as a researcher I want to be able to read every word that Yasser Arafat said on the phone. In a sense an over-zealous intelligence agency becomes the researcher's friend.

MP: Yet the warning that you put out there in your article about the intelligence supermarket ${ }^{17}$ still applies; the weeders will never be Chelsea Manning, they will never release the whole picture but will select. They might select a fuller picture, but they might still withhold important information.

RA: This is where I think political scientists are really important. Historians have always accepted, I think too willingly, the limits of their methodology. They go into an archive with a set of questions, they don't find the answers to the questions they want, but they find another set of answers that have very little to do with the questions they were initially asking. And they write that stuff up. But that means the weeders are setting the agenda; the weeders have allowed me to see this stuff, so I write about this stuff. In the UK case the weeders by removing relatively small amounts of stuff change the picture quite significantly. I don't think Britain was assassinating people every day, but I think Britain conducted some assassinations. The fact that we can't see that stuff radically changes our picture of what British intelligence was about. It is often represented as this very sober constitutional process of JIC and assessments and thinking about the world, and people who are effectively dons from Oxford colleges thinking there about how many missiles do the Chinese have, and so on. So that changes the picture. However, I think the great thing about political scientists is if you are a political scientist the only limit on what you can find out is your budget because you are more conditioned to get on train or a plane and go an interview people. For political scientists there are no secrets, just lazy researchers. It's just about how much time and money do you have to go and interview people. What worries me about a lot of British intelligence studies is that our time is limited, our money is limited, and we go to the National Archives and we attack the low-hanging fruit. Historians

\footnotetext{
${ }^{17}$ Richard J. Aldrich, 'Grow Your Own: Cold War Intelligence and History Supermarkets, Intelligence and National Security, Vol.17, No.1 2002: 135-52.
} 
who work in other difficult fields - social history - have gone down the road of interviewing. I am fascinated as to why British intelligence studies academics have not done more interviews. For me the person who has probably done more interviews than anyone else is Nigel West, who has primarily worked through a social network. Look at his book on the secret war for the Falklands, ${ }^{18}$ one of my favourite books of all time. It uses an oral history methodology which historians of British intelligence have largely rejected in favour of the National Archives and has allowed Nigel to write an amazing book which no university historian could write.

MP: After this, you worked on the book on GCHQ?

RA: There was the interlude because my books on Intelligence and the War Against Japan and The Hidden Hand were published in 2000 and 2001. The GCHQ book wasn't published until 2010. I did two volumes of Second World War diaries in the middle and although only a small amount of that was about intelligence, it was an expression of this methodological anxiety. I love diaries precisely because they are not created by the state. They are often an act of rebellion. But always, between 2001 and 2009, on the back-burner was the GCHQ project.

MP: Why did you choose to write a book about GCHQ? The Introduction in that book is titled 'GCHQ - The Last Secret? Was that part of the attraction?

RA: Well, Chris Andrew was telling us, even around 2002, that SIGINT was the 'big one' and the most important aspect of intelligence but the least written about. One former senior GCHQ person I interviewed described MI5 and MI6 as 'the tiddlers' and I think that was the moment when I thought, 'if they are the tiddlers, where is the whale? Oh It's you!'

I also liked the methodological challenge of attacking something that the weeders were definitely trying to suppress - SIGINT. Almost more than anything else this was a naughty thing. So I was already working on GCHQ and then the official histories of the UK agencies are commissioned. By 2005-06 it is clear that MI5 are going to have one, MI6 is going to have one, but GCHQ wasn't, and by 2007 I was working on GCHQ and still had hopes that GCHQ would do an official history. Around this time, I went to a talk by David Pepper in Oxford and at the dinner was Judie Hodsdon, who was Bill Bonsall's daughter - the one of the former directors - who was also one of the six people on the board of GCHQ. She was in

\footnotetext{
${ }^{18}$ Nigel West, The Secret War for the Falklands: The SAS, Mi6 and the War Whitehall Nearly Lost (London: Little, Brown, 1997).
} 
charge of its public relations. I sat next to her at the dinner and spent the entire dinner trying to persuade her that not publishing an official history was a bad idea, that public understanding was critical, that MI5 and MI6 had got it right. I tried to explain to her that by not writing your history you don't prevent history from being written, all you do is ensure someone else writes it, not you, and you lose control of your history. She was rather adamant this was not going to happen. What I didn't say to her during dinner was that the person you are going to lose control to is me, because I'm already on chapter thirteen of my book on GCHQ.

MP: It must have been a huge challenge methodologically, one where that lateral approach was possibly more important than ever?

RA: Well, it's the only book where I worried that a police car would turn up on my drive, that the police would take the contents of my office and walk away with them. It's the only time I've become security-aware in terms of my research. In discussions with my agent, Andrew Lownie, we called it the 'Bletchley Park project' and moved it back in terms of time. I typed every word on a laptop that was disabled to prevent it from connecting to the internet, which was a real pain because when you are writing something you need access to Google all the time. So I had a separate desk-top that I was doing Google on, but all the writing went onto this laptop. And then there was the transfer to the publishers. That chapters had to be hand-delivered on discs. I had to persuade my editor to look at it on a desk-top where he pulled the ethernet cable out. All very convoluted, but subsequently Matthew Aid, (who I first met in a student hostel in Washington DC in 1986) who I have learnt a lot from, explained to me that when working on his book on the National Security Agency (NSA) in the $\mathrm{US}^{19}$, was convinced that everything he typed on his desk-top was visible to the American government. I think the US government had the manuscript of his book on NSA before the publisher! And that informed my own approach in terms of communications security. Then I was worried about government turning up and taking my documents. I was worried about an injunction, because government tends to injunct very close to the publication date. So I then worked with the publisher and we were slightly fuzzy about the publication date. We publicised the publication date of the Australian edition, which was actually two months later, and as we got closer to the publication date, D-Notice kept calling us up and saying 'we understand you are doing this book on GCHQ, can we see it, please?' I told them that it was

\footnotetext{
${ }^{19}$ Matthew Aid, The Secret Sentry: The Untold History of the National Security Agency (London: Bloomsbury, 2009).
} 
just based on what I had been able to find in the National Archives, so everything that is in the book has been deliberately released by a government official, so you don't have to worry at all. And they replied, 'That's very good, we're very pleased, but would you please send it to us.' I started to send them the early chapters, the Second World War, 1946, 1947, but of course what we had done is we had created a slightly deceptive timeline. Eventually I got a call from the Deputy Secretary and I was invited down to GCHQ for a cup of tea. They were really nice, it was the GCHQ Press Officer and someone who worked closely with the Director, and they asked me when the book was going to be published. At this point I knew that two days ago they had started to sell copies in Waterstone's in Trafalgar Square in London, and it was clear they didn't know the timeline of the publication of the book - which is either very reassuring or very worrying depending on your point of view. Nervously, I reached under the table into my lap-top bag and I produced two copies and handed them over. They were really nice about it. They clearly understood this was an archival project and what they really wanted was a heads-up if there was anything bad in the book that journalists would call them about. Actually, they weren't interested in anything that had happened pre1996. These were two young people who joined the organisation in 2000; 1996 and the David Omand reorganisation was medieval history and anything before that ancient. The fascinating thing was that I had rather harsh censorship of my book, but it wasn't GCHQ, it wasn't government, it was the publishers who thought that the chapters on crypto and maths were boring. So the stuff that I think GCHQ would have found most sensitive, the publishers wouldn't print.

Methodologically GCHQ is the favourite book I worked on, partly because it was difficult and interesting, partly because methodologically it raised so many questions about 'how do we know what we know?' There's always that issue when thinking about a future project, and I can't think of anything more fun than back in 2008 working on GCHQ and wondering if the police are going to break the door down! And I love GCHQ because of the characters. In a very lovely way GCHQ were a bunch of weirdos and studying them was so much fun. 2008 was also the year when I moved to Warwick and started working as a team with Christopher Moran and Simon Willmetts on the 'Landscapes' project. Having delightful colleagues around you who understand your research makes such a difference.

MP: And now a decade after your book was published, we await publication of the, finally commissioned, official history of GCHQ, currently being written by the eminent historian of intelligence John Ferris. 
RA: Clearly John has been given a different set of conventions to, say, the MI5 authorised history. Chris Andrew seems to have been allowed to walk into the MI5 archive and wander around at liberty. It appears that privilege is not going to be extended to John Ferris. I'm still pleased it is being done because Intelligence Studies, rather like medieval history, is a collective project. It's difficult and we need to do it as a team project. There may be officially imposed limits to the John Ferris history but it will open doors for further research. The great thing is that all those files that GCHQ allow John to see are going to be sent to the National Archives and then people like me are going to get to comb over them, so more is more. So, I'm really pleased they are doing it.

The thing I felt I couldn't go near or was reluctant to go near when I was writing my book was Northern Ireland. I know the peopler who worked as the interface between Northern Ireland Special Branch and GCHQ, but I think there would have been immense legal problems and I think it would just have been too difficult. I know that there was a section of Chris Andrew's history of MI5, that has also not been published because of legal difficulties and objections by the RUC Special Branch. What would I love to read if I could just go into the magical bookshop full of books that don't exist? I would love to pull down a volume on the interface between GCHQ and the Troubles. (It sits on the mystical bookshelf there - right next to the book on what NSA learned by listening to Yasser Arafat's phone calls for decades.) There is a great book to be written on the Troubles, but whether we will ever read it, I don't know. There are clearly constituencies who don't want that book to be written.

MP: The Black Door, about British prime ministers and secret intelligence, is your latest book, co-authored with Rory Cormac, and it is another big book in the vein of The Hidden $H a n d$ and $G C H Q$ and a vast canvas. It isn't an explicitly comparative study, but in the way in which it covers every administration since Asquith it does allow for comparative reflection on the question of how well or astutely prime ministers handled intelligence. Did you draw any conclusions on that question?

RA: There was that implicit comparative dimension. If it was the 'university challenge' of British prime ministers, who wins the prize for being the best consumer? Actually, it would be John Major with his ability to understand the limitations of intelligence. He brings a Treasury mind to it and also his understanding of management and so becomes quite interested in the financial management. All of the heads of the agencies and the senior managers felt that he was the perfect customer. In talking to heads of agencies about who was 
the best customer, the answer was John Major, particularly in the Maastricht negotiations SIGINT against our European allies, absolutely fascinating.

In terms of Tony Blair as a customer for intelligence, Blair makes me think of Lyndon Johnson. Leaders are often defined by a single event. Lyndon Johnson, despite the Great Society and the promotion of civil rights, he is only remembered for the Vietnam War. Similarly, Blair in his early years did some amazing things - for example, the Good Friday Agreement in Northern Ireland and deploying intelligence for peace around it. Here was someone who was an effective, sensitive customer for intelligence up to 9/11. But we will only remember Blair for post-9/11, for the Iraqi WMD. He actually used intelligence well in Sierra Leone, but we are not going to remember that. We will only remember WMD. We will only remember Iraq. And maybe that is right because it has cost the lives of so many people in Iraq.

The single thing that I think comes out of that book for Rory and I is that Britain's achievements in intelligence are about creating a central managerial framework. Often intelligence, and the expansion of the British intelligence community from small to big, from amateur to professional, is associated with Churchill, but actually it was a double act; Churchill and Attlee. It is Attlee who regularises and systematise Churchill's achievements. Churchill was the grit in the oyster but the JIC was created to resist Churchill more than anything. We also see that regardless of ideology, prime ministers and cabinet ministers love intelligence. Harold Wilson loved intelligence. As a Cabinet minister Tony Benn loved intelligence - he adored the SAS. And these are kinds of slightly improbable things that I really like.

MP: Can I turn to the future of Intelligence Studies. It has come a long way in the last ten or fifteen years. The range of publications has mushroomed, the number of courses on intelligence and the number of countries in which they are offered have grown. What do you think the future of Intelligence Studies looks like? Where does it go from here? What will it look like in another ten or fifteen years' time?

RA: The good thing is that it has become massively interdisciplinary. It is no longer something that is done primarily by historians or political scientists. The fact that engineers are doing it, the fact that Theatre Studies is doing it, Education Studies is doing it, the fact that one of the biggest projects of the last five years, Lina Dencik's ESRC project on Snowden and the surveillance society at Cardiff University, is based in a School of 
Journalism, Media and Culture, it's great that there is that disciplinary diversity. ${ }^{20}$ What do I worry about? A lot of the expansion of Intelligence Studies has been funded by the budgetary expansion of intelligence as a practitioner area since 9/11. Budgets have double and doubled again, the size of the agencies has doubled and doubled again. To what extent are we part of that? Historically, will we look back on this period and see that Intelligence Studies has mushroomed but are we really an outgrowth of the expansion of counter-terrorism activity since $9 / 11$ ?

MP: And how far do you think that is the business of Intelligence Studies to be a provider of solutions for government? Is that one possible future for it?

RA: Well, I'm going to side-step the question and say that I think government has lost control of intelligence. The big intelligence actors now are platform capitalist ventures like Google and Microsoft. These are the big data hulks, the people who understand what is going on in the world. There have always been corporations that do 'big intelligence' - Shell, BP but those corporations have historically been rooted in states, they have had national allegiances. Microsoft and Amazon, for example, don't have that same kind of infrastructure in any country. They can move their servers around. Amazon is not tied to warehouses and infrastructure in any particular country, all it needs to do is rent more server space, which could be anywhere. And these are the people who have the commanding heights of information.

I actually think that by 2050 'intelligence' will be an historical word. We will talk about something else. We will have courses in 'Knowledge-Intensive Security', 'Big Data' and so on instead.

MP: So the idea of 'Intelligence Studies' has a finite life?

RA: Yes, I think we have a great future behind us.

MP: Perhaps an appropriate note on which to end! Thank you so much Richard. It has been a really fascinating discussion.

\footnotetext{
${ }^{20}$ Lina Dencik and Jonathan Cable, 'The advent of surveillance realism: Public opinion and activist responses to the snowden leaks,' International Journal of Communication 11 (2017): 763-781.
} 


\section{Richard J. Aldrich: A Select Bibliography}

'Imperial Rivalry: British and American Intelligence in Asia, 1942-6', Intelligence and National Security, Vol.3, No.1 1988): 5-53.

'Unquiet in Death: the post-war survival of the Special Operations Executive, 1945-1951', Anthony Gorst, Lewis Johnman, and W. Scott Lucas (eds.) Contemporary British History, 1931-1961: Politics and the Limits of Policy (London: Pinter 1991): 193-218.

'Soviet Intelligence, British Security and the End of the Red Orchestra', Intelligence and National Security, Vol.6, No.1 1991: 196-217.

'Conspiracy or Confusion: Churchill, Roosevelt and Pearl Harbor', Intelligence and National Security, Vol.7, No.3 1992: 335-47.

British Intelligence, Strategy and the Cold War, 1945-51, edited (London: Routledge, 1992).

The Key to the South: Britain, the United States and Thailand During the Approach of the Pacific War, 1929-42 (Oxford: Oxford University Press, 1993).

Intelligence, Defence and Diplomacy: British Policy in the Post-war World, co-edited with Michael Hopkins (London: Frank Cass, 1994).

'Intelligence, Anglo-American Relations and the Suez Crisis, 1956', Intelligence and National Security, Vol.9, No.3 1994: 544-55.

'Never-Never Land or Wonderland? British and American Policy on Intelligence Archives', a revised version of the above reprinted in the US Government professional journal Studies in Intelligence, Vol.38, No.5 1995: 17-26.

'The Waldegrave Initiative and Secret Service Archives: New Documents and New Policies', Intelligence and National Security, Vol.10, No.2 1995: 192-7.

'OSS, CIA and European Unity: The American Committee on United Europe, 1949-1960', Diplomacy and Statecraft, Vol.8, No.1 1997: 184-227.

'The Perfect Cover: British Intelligence, the Soviet Fleet and Distant Water Trawler Operations 1964-74' (with Mason Redfearn), Intelligence and National Security, No.12, No.3 1997: 166-80.

'The British Secret Intelligence Service (MI6) and the Pacific War', in Modern Asian Studies, Vol.32, No.1 1998: 179-218. 
'Did Waldegrave Work? The Impact of Open Government Upon British History', Twentieth Century British History, Vol.9, No.1 1998: 111-26.

'American Intelligence and The British Raj: The OSS, the SSU and India, 1942-7', Intelligence and National Security, Vol.13, No.1 1998: 130-62.

'British Intelligence and the Anglo-American "Special Relationship" during the Cold War', Review of International Studies, Vol.24, No.3 1998: 331-51.

Espionage, Security and Intelligence in Britain, 1945-1970: Documents in Contemporary History, edited (Manchester: Manchester University Press, 1998)

'The Struggle for the Mind of European Youth: the CIA and European Movement Propaganda, 1948-60' in G.D. Rawnsley (ed.), Cold War Propaganda in the 1950s (London: Macmillan, 1999): 183-203.

'Legacies of Secret Service: Renegade SOE and the Karen Struggle in Burma, 1948-50,' Intelligence and National Security, Vol.14, No. 4 1999: 130-148.

The Clandestine Cold War in Asia, 1945-65: Western Intelligence, Propaganda, Security and Special Operations, co-edited with Gary Rawnsley and Ming-yeh Rawnsley (London: Frank Cass, 2000).

Intelligence and the War Against Japan: Britain, America and the Politics of Secret Service (Cambridge: Cambridge University Press, 2000).

'Signals Intelligence and GCHQ, 1945-70' in Intelligence and National Security, Vol.16, No.1 2001: 67-96.

'Liberation: Rolling Back the Frontiers of Clandestine Cold War History?', Cold War History, Vol.1, No.2 2001: 122-134.

The Hidden Hand: Britain, America and Cold War Secret Intelligence (London: John Murray, 2001).

'Grow Your Own: Cold War Intelligence and History Supermarkets, Intelligence and National Security, Vol.17, No.1 2002: 135-52.

'Putting Culture into the Cold War: From Cultural Relations Department to IRD', Intelligence and National Security, Vol.18, No.2 2003: 109-33. 
'From Ireland to Bosnia: Intelligence Support for UK Low Intensity Operations', in Ben de Jong, Robert Steele and Wies Platje (eds.) Peacekeeping Intelligence: Emerging Concepts for the Future (Oakton: OSS International Press, 2003): 73-100.

Witness to War: Diaries of the Second World War in Europe and the Middle East, edited (Doubleday, 2004).

'Transatlantic intelligence and security co-operation', International Affairs, Vol.80, No.3 2004: $331-55$

'Policing the Past: Official History, Secrecy and British Intelligence since 1945', English Historical Review, Vol.119, No.483 2004: 922-53.

'Whitehall and the Iraq War: The UK's Four Intelligence Enquiries', Irish Studies in International Affairs, Vol.16, No.1 2005: 73-88.

The Faraway War: Personal Diaries of the Second World War in Asia and the Pacific, edited (London: Doubleday, 2005).

'The Secret State', in Harriet Jones and Keith Middlemas (eds.) Blackwell's Companion to Contemporary Britain, 1939-2000 (Oxford: Blackwell, 2005): 333-50.

'Contending Cultures of Counter-terrorism: Transatlantic Convergence or Divergence?' (with Wyn Rees), International Affairs, Vol.81, No.5 2005: 905-23.

'The US-UK Intelligence Alliance in 1975: Economies, Evaluations and Explanations', Intelligence and National Security Vol.21, No.4 2006: 557-67.

"'Even had I wanted to": Intelligence and Special Operations in the Falklands Campaign', International Relations, Vol.20, No.3 2006: 378-83.

'British Intelligence, Security and Western Co-operation in Cold War Germany: The Ostpolitik Years', in Beatrice de Graaf, Ben de Jong, Wies Platje (eds.) Battleground Western Europe: Intelligence Operations in German and the Netherlands in the Twentieth Century (Amsterdam: Uitgeverij Het Spinhuis, 2007): 123-146.

'US-European Intelligence Co-operation on Counter-terrorism: Low Politics and Constraint', British Journal of Politics and International Relations Vol.11, No.1 2009: 122-40.

'Global Intelligence Co-operation versus Accountability: New Facets to an Old Problem', Intelligence and National Security, Vol.24, No.1 2009: 26-56. 
'The UK Security State', in Matthew Flinders, Andrew Gamble, Colin Hay \& Mike Kenny (eds.) The Oxford Handbook of British Politics (Oxford: Oxford University Press, 2009): 75270.

Secret Intelligence: A Reader, co-edited with Christopher Andrew \& Wesley K. Wark (Abingdon: Routledge, 2009).

'Beyond the Vigilant State? Globalization and Intelligence', Review of International Studies, Vol.35, No.4 2009: 889-904.

GCHQ: The Uncensored History of Britain's Most Secret Intelligence Agency (London: Harper Collins, 2010).

'Intelligence Co-operation in Theory and Practice', in H. Born and I. Leigh (eds.) International Intelligence Co-operation and Accountability (London: Routledge, 2010): 18-41.

'Persuasion: British Intelligence, the History Policeman and Official Information', in Patrick Major and Christopher Moran (eds.), Spooked: Britain, Empire and Intelligence Since 1945 (Cambridge: Cambridge Scholars, 2010): 29-50.

"'A profoundly disruptive force": The CIA, Historiography and the impact of Globalization', Intelligence and National Security, Vol.26, No.2/3 2011: 1-20.

"'A skeleton in our cupboard" British Interrogation Procedures in Northern Ireland', in M. Goodman and R. Dover (eds.) Learning from the Secret Past: Cases in British Intelligence History (Washington DC: Georgetown University Press, 2011):161-189.

'Escaping From American Intelligence: Culture, Ethnocentrism and the Anglosphere' (with John Kasuku), International Affairs, Vol.89, No.5 2012: 1009-28.

'Whitehall wiring: The Communications-Electronics Security Group and the struggle for secure speech', Public Policy and Administration, Vol.28, No.2 2013: 178-195.

'CIA History as a Cold War Battleground: The Forgotten First Wave of Agency Narratives' in Christopher Moran and Christopher Murphy (eds.) Intelligence Studies in Britain and the US: Historiography Since 1945 (New York: Columbia University Press/Edinburgh: Edinburgh University Press, 2013): 10-27. 
'Risks and Rewards? Costs and Benefits? British Intelligence During the Cold War', in Karina Urbach and Jonathan Haslam (eds.) Secret Intelligence in the European States System, 19181989 (Stanford: Stanford University Press, 2013):149-70.

'Counting the Cost of Intelligence: The Treasury, National Service and GCHQ', English Historical Review, Volume CXXVIII, Issue 532 2013: 596-627.

'The Future of Cyber-Resilience in an Age of Global Complexity' (with Lewis Herrington), Politics, Volume 33, Issue 4 2013: 299-310.

Spying on the World: The Joint Intelligence Committee and Events which Shaped History, coedited with Michael Goodman and Rory Cormac (Edinburgh: Edinburgh University Press, 2014).

'GCHQ and Computing: Teddy Poulden, IBM and ICL', in M. Murfett (ed.) Shaping British Foreign and Defence Policy in the Twentieth Century (London: Palgrave, 2014): 240-53.

'The 100 billion dollar brain: Central intelligence machinery in the UK and the US', International Affairs, Vol.90, No.2 2015: 393-406.

'American Journalism and Landscapes of Secrecy: Tad Szulc, Cuba and the CIA', History, Vol.100, No.339 2015: 189-209.

The Black Door: Spies, Secret Intelligence and British Prime Ministers, co-authored with Rory Cormac (London: William Collins, 2016).

'The Intellectual Redneck: William Odom and NSA', in Christopher Moran et al (eds.) Spychiefs: Volume 1 Intelligence Leaders in the United States and United Kingdom (Washington, DC: Georgetown University Press, 2017): 183-205.

'Trump and the CIA: Borrowing from Nixon's Playbook', with Christopher Moran, Foreign Affairs, April 2017; https://www.foreignaffairs.com/articles/2017-04-24/trump-and-cia.

'Strategic Culture as a Constraint: Intelligence Analysis, Memory and Organizational Learning in the Social Sciences and History', Intelligence and National Security, Vol.32, No.5 2017: 625-35.

'Grey is the New Black: Covert Action and the Rise of Implausible Deniability', with Rory Cormac, International Affairs, Vol.94, No.3 2018: 477-95. 
'Secrets, Hostages and Ransoms: British Kidnap Policy in Historical Perspective', with Lewis Herrington, forthcoming, Review of International Studies, 2018.

"'Delayed Disclosure": Whistle-blowers, National Security and the Nature of State Secrecy', with Christopher Moran, forthcoming, Political Studies, 2018.

'Ambient Accountability: Intelligence Services in Europe and the Decline of Secrecy', with Daniela Richterova, forthcoming, West European Politics, Vol.41, No.4 (2018). 